\title{
Environmental Effect on Growth and Characteristics of Eucalyptus Wood
}

\author{
Thaís Pereira Freitas ${ }^{1}$ (D) José Tarcisio da Silva Oliveira ${ }^{2}$ (D), Juarez Benigno Paes ${ }^{2}$ (D), \\ Graziela Baptista Vidaurre ${ }^{2}$ (D) José Luis Lima ${ }^{3}$ (i) \\ ${ }^{1}$ Universidade Federal de Viçosa (UFV), Viçosa, MG, Brasil \\ ${ }^{2}$ Universidade Federal do Espírito Santo (Ufes), Jerônimo Monteiro, ES, Brasil \\ ${ }^{3}$ Suzano S.A, Aracruz, ES, Brasil
}

\begin{abstract}
The objective of this work was to evaluate environmental effect on growth, wood basic density and anatomical characteristics of Eucalyptus grandis $\times$ Eucalyptus urophylla clones for pulp production. The studied clones were from 6.5-year-old plantations of Fibria Celulose company, located in two places: Nova Almeida (ES) and Posto da Mata (BA). The total and commercial heights, diameter at breast height $(\mathrm{DBH})$, wood and bark volume (dendrometric characteristics), heartwood and sapwood percentages, wood basic density and wood fibers and vessels were evaluated. The heartwood and sapwood percentage and vessel frequency were the only characteristics not influenced by the growth site among the studied parameters. On the other hand, tree height (total and commercial) was considered the most influenced by the environment.
\end{abstract}

Keywords: Eucalyptus grandis $\times$ Eucalyptus urophylla, wood characterization, growth site. 


\section{INTRODUCTION AND OBJECTIVES}

According to the Brazilian Tree Industry, Ibá (2015), $34 \%$ of 7.74 million hectares of trees planted in Brazil belonged to companies in the pulp and paper segment, with eucalyptus being used as the raw material by industries in this sector, representing approximately $88.4 \%$ of the total in natura wood consumption in 2014, which was equal to 69.91 million $\mathrm{m}^{3}$, and with Pinus accounting for $8.08 \%$ of this consumption.

In recent decades, Brazil has had an enviable evolution in the productivity of eucalyptus forests, from $15 \mathrm{~m}^{3} \mathrm{ha}^{-1}$ year ${ }^{-1}$ in the 1970 s to a national average of $45 \mathrm{~m}^{3} \mathrm{ha}^{-1}$ year ${ }^{-1}$ (Gomide et al., 2010). According to Gomide et al. (2005), forest plantations of the last generation of eucalyptus clones belonging to the main Brazilian pulp companies have the highest global levels of average annual increase (IMA).

Tree growth is influenced by its genetic factor of hereditary origin and by its environment conditions, and this interaction will also influence the formed wood properties. Brazil has a great variety of edaphoclimatic conditions, and therefore it is important that developed clones have the least effect of the growth site on the technological characteristics of their wood in order to ensure producing a raw material that is as homogeneous as possible (Gouvea, et al., 2012).

Although characterizing wood is expensive, it is of fundamental importance, because in addition to highly productive forests, selecting genetically superior materials in yield and quality of the final product is desired; specifically regarding pulp production, several parameters can be used for determining the wood quality, with these being classified as: physical, where basic density is the main parameter; chemical, such as carbohydrate, lignin and extractive contents; and anatomical, such as the percentage and dimensions of the wood fibers and vessels (Gomide et al., 2010).

In this context, the objective of this work was to evaluate the environment effect on the growth, wood basic density and anatomy of the wood from Eucalyptus grandis $\times$ Eucalyptus urophylla clones for pulp production.

\section{MATERIALS AND METHODS}

The wood used in this study originated from seven 6.5-year-old Eucalyptus grandis $\times$ Eucalyptus urophylla clones, from clonal test plantation areas with $3 \times 3 \mathrm{~m}$ spacing, of the Fibria Celulose S.A. company in two locations, Nova Almeida, Espírito Santo (ES), and Posto da Mata, Bahia (BA), with five trees being used per clone.

The local edaphoclimatic characteristics (Table 1) are based on the historical series of the years in which the plantations were installed (2007-2014) and were obtained from the climate monitoring stations that compose the Fibria Celulose S.A. company system.

Trunk diameters were measured using the Smalian method with and without bark in 16 positions along the tree, as well as their respective commercial and total heights to estimate wood and bark volumes. The bark volume was obtained by the difference between the trunk volume with and without bark.

Two discs were removed from each tree at breast height (DBH) taken at $1.30 \mathrm{~cm}$ from the ground, and discs positioned in $0 \%, 25 \%, 50 \%, 75 \%$ and $100 \%$ of the commercial height of the tree. Two wedges were then removed from the disk of each position in opposite directions to determine the basic density in the longitudinal direction of the tree, and the second disk obtained at the DBH was sampled in the transition

Table 1. Soil and climate characteristics of the growth locations of seven Eucalyptus grandis $\times$ Eucalyptus urophylla clones.

\begin{tabular}{|c|c|c|c|c|c|c|c|c|c|}
\hline Loc. & $\begin{array}{c}P \\
\left.\left(\mathrm{~mm}^{\text {year }}\right)^{-1}\right)\end{array}$ & $\begin{array}{c}\mathrm{T} \\
\left({ }^{\circ} \mathrm{C}\right)\end{array}$ & Soil type & Soil texture & $\mathrm{OM}_{1}$ & $\mathrm{OM}_{2}$ & AWC & Altitude & Relief \\
\hline NA & 1247.3 & 23.3 & $\begin{array}{c}\text { Typical yellow } \\
\text { Argisol }\end{array}$ & $\begin{array}{l}\text { Medium/ } \\
\text { clayey }\end{array}$ & 2.7 & 2.3 & 260 & 43.0 & $\begin{array}{l}\text { Smooth } \\
\text { undulated }\end{array}$ \\
\hline PM & 1455.6 & 24.3 & $\begin{array}{c}\text { Dystrophic } \\
\text { yellow Argisol to } \\
\text { prominent }\end{array}$ & $\begin{array}{l}\text { Sandy/ } \\
\text { medium/ } \\
\text { clayey }\end{array}$ & 1.0 & 0.9 & 157 & 33.3 & Flat \\
\hline
\end{tabular}

Loc.: location; NA: Nova Almeida (ES); PM: Posto da Mata (BA); P: mean precipitation (mm year-1); T: mean annual temperature; $\mathrm{OM}_{1}$ : organic matter by colorimetry in the first layer of soil $\left.(\mathrm{dag} \mathrm{kg})^{-1}\right) ; \mathrm{OM}_{2}$ : organic matter by colorimetry in the second layer of soil $\left(\mathrm{dag} \mathrm{kg}^{-1}\right)$; AWC: available water capacity in the soil layer up to 2 meters deep ( $\mathrm{mm}$ ). 
region between heartwood and sapwood (peripheral core) for characterizing the anatomical wood structure.

In order to quantify the heartwood and sapwood percentages from end to end of each disc from each position, two perpendicular lines were drawn through the center of the pith, and then measurements of the total diameter and heartwood diameter were performed, the sapwood thickness was obtained by the difference. Next, the heartwood and sapwood percentages were calculated for each disc, then the mean value was obtained per tree.

Basic density was determined according to the Norms of the Brazilian Association of Technical Standards NBR 6230 (ABNT, 1985) and NBR 11941 (ABNT, 2003). After obtaining the basic density at each position along the trunk, the weighted basic density was calculated by using the volume of the logs from the obtained sections.

The anatomical characterization of the wood was performed according to the criteria of the Pan American Standards Commission - Copant (1974), and the tangential diameter $(\mu \mathrm{m})$ and frequency (no. $\mathrm{mm}^{-2}$ ) of the vessels were measured, as well as the fibers' length $(\mu \mathrm{m})$, width $(\mu \mathrm{m})$, lumen diameter $(\mu \mathrm{m})$ and wall thickness $(\mu \mathrm{m})$. Dissociation of the anatomical elements for fiber measurement was performed according to the method described by Dadswell (1972). Twenty-five vessels and 25 fibers were measured for each treatment using an optical microscope with an image capture system and using Axio-Vision software.

The experiment was conducted in a completely randomized design with a $2 \times 7$ factorial arrangement, with clone (7 levels) and location (two levels) as factors and five replications. When the interaction effect between clone $\times$ location was significant by the F-test analysis of variance $(\mathrm{p} \leq 0.05)$, thereby evidencing the existence of dependence between the considered factors (clone and local), the interaction and comparison between averages was analyzed by the Scott-Knott test $(\mathrm{p} \leq 0.05)$.

\section{RESULTS AND DISCUSSION}

\subsection{Dendrometric characterization, heartwood and sapwood percentages, and wood basic density}

The variations occurring in the evaluated dendrometric parameters for the same clone at different sites, as well as for the same site and different clones are related to the site's edaphoclimatic conditions and the hereditary genetic factor, which directly influence tree growth and productivity, and consequently may also interfere with the wood quality.

The clone $\times$ location interaction was significant $(\mathrm{p} \leq 0.05)$ for all the evaluated dendrometric characteristics, for the weighted basic densities and DBH (Tables 2 and 3), indicating the existence of dependence between the factors, and therefore the interaction and comparison of means for these variables were carried out at 5\% significance (Table 4). Heartwood and sapwood contents were the only characteristics not influenced by the clone $\times$ location interaction (Table 3 ).

The commercial and total heights were not affected by clones in Nova Almeida-ES, but were the most influenced by the site, presenting significant difference between the sites for five of the seven studied clones. On the other hand, the bark volume and the weighted average basic density were the characteristics that had less effect influenced by the environment, presenting significant difference of the means between the sites for only two of the seven evaluated clones.

Table 2. Summary of variance analysis for the dendrometric characteristics of wood.

\begin{tabular}{lcccccc}
\multicolumn{1}{c}{ VF } & DF & \multicolumn{5}{c}{ Means squared } \\
\hline & & CH & TH & DBH & WV & BV \\
CL & 6 & $21.021^{* *}$ & $24.927^{* *}$ & $26.8015^{* *}$ & $0.076^{* *}$ & $0.003^{* *}$ \\
L & 1 & $210.335^{* *}$ & $212.979^{* *}$ & $78.546^{* *}$ & $0.436^{* *}$ & $0.002^{*}$ \\
$\mathrm{CL} \times \mathrm{L}$ & 6 & $19.396^{* *}$ & $17.405^{* *}$ & $19.418^{* *}$ & $0.083^{* *}$ & $0.001^{*}$ \\
Error & 42 & 1.963 & 2.201 & 6.106 & 0.011 & 0.000 \\
\hline $\mathrm{CVe}$ & & 4.9556 & 4.8363 & 11.474 & 18.710 & 20.053 \\
\hline
\end{tabular}

VF: variation factor; DF: degrees of freedom; CL: clone; L: location; CL $\times$ L: clone $\times$ location interaction; CVe: experimental coefficient of variation (\%); $\mathrm{CH}$ : commercial height $(\mathrm{m})$; TH: total height $(\mathrm{m})$; DBH: diameter at breast height $(\mathrm{cm})$; WV: wood volume $\left(\mathrm{m}^{3}\right)$; BV: bark volume $\left(\mathrm{m}^{3}\right)$; ${ }^{* *}$ : significant $(\mathrm{p} \leq 0.01)$; ${ }^{*}$ significant $(0.01>\mathrm{p} \leq 0.05)$ by the F-Test. 
Table 3. Summary of variance analysis for heartwood and sapwood content and average weighted basic density and DBH of the wood.

\begin{tabular}{lccccc}
\multicolumn{1}{r}{ VF } & DF & \multicolumn{4}{c}{ Means squared } \\
CL & 6 & $112.932^{* *}$ & $112.932^{* *}$ & $0.006^{* *}$ & $0.007^{* *}$ \\
$\mathrm{~L}$ & 1 & $0.108^{\text {ns }}$ & $0.108^{\text {ns }}$ & $0.003^{* *}$ & $0.000^{\text {ns }}$ \\
CL $\times$ L & 6 & $45.499^{\text {ns }}$ & $45.499^{\text {ns }}$ & $0.002^{* *}$ & $0.004^{* *}$ \\
Error & 56 & 23.388 & 23.388 & 0.000 & 0.000 \\
\hline CVe & & 8.614 & 11.027 & 2.886 & 3.795 \\
\hline
\end{tabular}

VF: variation factor; DF: degrees of freedom; CL: clone; L: location; CL $\times$ L: clone $\times$ location interaction; CVe: experimental coefficient of variation (\%); WMbd: weighted mean basic density $\left(\mathrm{g} . \mathrm{cm}^{-3}\right)$; BDdbh: basic density in DBH $\left(\mathrm{g} . \mathrm{cm}^{-3}\right)$; ${ }^{* *}$ : significant $(\mathrm{p} \leq 0.01)$; ${ }^{\text {ns: not }}$ significant $(\mathrm{p}>0.05)$ by the F-Test.

Wood basic density is one of the most important parameters due to its ease in determining, and it is an ideal characteristic to manipulate from the point of view of improvement due to the research in this parameter showing great variation, high heritability and low interaction of genotype $\times$ environment (Ferreira, 1994).

Thus, characteristics such as basic density are desirable in genetic improvement, since the phenotypic variation in characteristics with high heritability is mainly due to genetic variation, and therefore less influenced by environmental variations (Sturion, 2008). This trend can be observed in the present study, since there was high influence by the genetic material on the basic density, which obtained a greater variation between the average values of the clones than between the sites (Table 4).

A study carried out with eucalyptus clones belonging to the main Brazilian pulp companies revealed basic density values varying from $0.465 \mathrm{~g} . \mathrm{cm}^{-3}$ to $0.490 \mathrm{~g} . \mathrm{cm}^{-3}$, and reported that the new projects to increase production capacity of the mills and to deploy new units have prioritized the use of wood with density close to $0.50 \mathrm{~g} . \mathrm{cm}^{-3}$ (Gomide et al., 2005). The values found by the last authors were

Table 4. Multiple comparison among averages for dendrometric characteristics and weighted average basic density and the DBH for the 6.5-year-old E. grandis $\times$ E. urophylla clones in both locations.

\begin{tabular}{|c|c|c|c|c|c|c|c|c|}
\hline Var. & Loc. & Clone 1 & Clone 2 & Clone 3 & Clone 4 & Clone 5 & Clone 6 & Clone 7 \\
\hline \multirow{2}{*}{$\mathrm{CH}$} & NA & $31.75 \mathrm{aA}$ & $29.68 \mathrm{aA}$ & $31.10 \mathrm{aA}$ & $29.40 \mathrm{aA}$ & $29.95 \mathrm{aA}$ & $30.58 \mathrm{aA}$ & $29.00 \mathrm{aA}$ \\
\hline & $\mathrm{PM}$ & $23.09 \mathrm{cB}$ & $24.48 \mathrm{cB}$ & $30.33 \mathrm{aA}$ & $29.80 \mathrm{aA}$ & $26.59 \mathrm{bB}$ & $27.19 \mathrm{bB}$ & $22.85 \mathrm{cB}$ \\
\hline \multirow{2}{*}{$\mathrm{TH}$} & NA & $34.01 \mathrm{aA}$ & $32.26 \mathrm{aA}$ & $33.58 \mathrm{aA}$ & $32.20 \mathrm{aA}$ & $32.42 \mathrm{aA}$ & $33.15 \mathrm{aA}$ & $30.77 \mathrm{aA}$ \\
\hline & $\mathrm{PM}$ & $25.48 \mathrm{cB}$ & $26.83 \mathrm{cB}$ & $32.55 \mathrm{aA}$ & $32.33 \mathrm{aA}$ & $29.03 \mathrm{bB}$ & $29.83 \mathrm{bB}$ & $25.05 \mathrm{cB}$ \\
\hline \multirow{2}{*}{$\mathrm{DBH}$} & NA & $23.4 \mathrm{bA}$ & $26.2 \mathrm{aA}$ & $21.6 \mathrm{bA}$ & $20.90 \mathrm{bA}$ & $23.10 \mathrm{bA}$ & $22.7 \mathrm{bA}$ & $20.7 \mathrm{bA}$ \\
\hline & $\mathrm{PM}$ & $17.0 \mathrm{bB}$ & $22.0 \mathrm{aB}$ & $24.2 \mathrm{aA}$ & $21.20 \mathrm{aA}$ & $22.30 \mathrm{aA}$ & $20.5 \mathrm{aA}$ & $17.5 \mathrm{bB}$ \\
\hline \multirow{2}{*}{ WV } & NA & $0.70 \mathrm{aA}$ & $0.84 \mathrm{aA}$ & $0.60 \mathrm{bA}$ & $0.54 \mathrm{bA}$ & $0.70 \mathrm{aA}$ & $0.66 \mathrm{aA}$ & $0.48 \mathrm{bA}$ \\
\hline & $\mathrm{PM}$ & $0.26 \mathrm{~dB}$ & $0.45 \mathrm{cB}$ & $0.72 \mathrm{aA}$ & $0.56 \mathrm{bA}$ & $0.57 \mathrm{bA}$ & $0.43 \mathrm{cB}$ & $0.29 \mathrm{~dB}$ \\
\hline \multirow{2}{*}{$\mathrm{BV}$} & NA & $0.10 \mathrm{bA}$ & $0.11 \mathrm{aA}$ & $0.10 \mathrm{aA}$ & $0.08 \mathrm{bA}$ & $0.13 \mathrm{aA}$ & $0.08 \mathrm{bA}$ & $0.09 \mathrm{bA}$ \\
\hline & PM & $0.06 \mathrm{cB}$ & $0.10 \mathrm{bA}$ & $0.13 \mathrm{aA}$ & $0.08 \mathrm{cA}$ & $0.12 \mathrm{aA}$ & $0.06 \mathrm{cA}$ & $0.06 \mathrm{cB}$ \\
\hline \multirow{2}{*}{ WMbd } & NA & $0.52 \mathrm{cB}$ & $0.50 \mathrm{cB}$ & $0.59 \mathrm{aA}$ & $0.52 \mathrm{cA}$ & $0.53 \mathrm{bA}$ & $0.54 \mathrm{bA}$ & $0.54 \mathrm{bA}$ \\
\hline & $\mathrm{PM}$ & $0.58 \mathrm{aA}$ & $0.53 \mathrm{cA}$ & $0.58 \mathrm{aA}$ & $0.52 \mathrm{cA}$ & $0.54 \mathrm{bA}$ & $0.53 \mathrm{cA}$ & $0.55 \mathrm{bA}$ \\
\hline \multirow{2}{*}{ BDdbh } & NA & $0.48 \mathrm{cB}$ & $0.48 \mathrm{cA}$ & $0.57 \mathrm{aA}$ & $0.47 \mathrm{cA}$ & $0.51 \mathrm{bA}$ & $0.50 \mathrm{bA}$ & $0.50 \mathrm{bA}$ \\
\hline & PM & $0.55 \mathrm{aA}$ & $0.48 \mathrm{bA}$ & $0.54 \mathrm{aB}$ & $0.46 \mathrm{bA}$ & $0.47 \mathrm{bB}$ & $0.47 \mathrm{bB}$ & $0.52 \mathrm{aA}$ \\
\hline
\end{tabular}

Var.: variables; Loc.: location; NA: Nova Almeida (ES); PM: Posto da Mata (BA); CH: commercial height (m); TH: total height (m); DBH: diameter at breast height $(\mathrm{cm})$; WV: wood volume $\left(\mathrm{m}^{3}\right)$; BV: bark volume $\left(\mathrm{m}^{3}\right)$; WMbd: weighted mean basic density $\left(\mathrm{g} . \mathrm{cm}^{-3}\right)$; BDdbh: basic density in DBH $\left(\mathrm{g} . \mathrm{cm}^{-3}\right)$. Means followed by the same lowercase letter in the row and uppercase in the column do not differ from each other by the Scott-Knott test $(\mathrm{p}>0.05)$. 
lower than those obtained in the present study for most of the clones, which presented a variation of $0.49 \mathrm{~g} . \mathrm{cm}^{-3}$ to $0.57{\mathrm{~g} . \mathrm{cm}^{-3}}^{-3}$ of tree basic density, but which remain within the range desired by the pulp mills.

The mean basic density for different 7 -year-old eucalyptus clones was 0.55 g.cm ${ }^{-3}$ (Trugilho, 2009), and a mean density of $0.505 \mathrm{~g} . \mathrm{cm}^{-3}$ was obtained for the 7-year-old E. grandis $\times$ E. urophylla (Carvalho \& Nahuz, 2001). These values are within the density range found in this study.

Regarding the DBH variation in the two sites, it was noted that there was only a significant statistical difference for clones 1,2 and 7 . When studying a 6-yearold Eucalyptus grandis $\times$ Eucalyptus urophylla hybrid destined to pulp production, Boschetti, Paes, Oliveira et al. (2015) found values close to those in this study for commercial height and $\mathrm{DBH}$, with mean values equal to $29.2 \mathrm{~m}$ and $21.45 \mathrm{~cm}$, respectively.

Note that the highest mean values of the evaluated dendrometric characteristics for all clones were always found in Nova Almeida-ES. The differences in terms of soil and climate in this site was the soil with medium/clayey texture and a higher amount of organic matter in the primary and secondary soil layers. Although precipitation did not vary much between the two sites, it was verified that there was a greater availability of water for plant growth in Nova Almeida, and these characteristics together resulted in better tree development.

In evaluating the influence of eucalyptus hybrid clone productivity planted at different locations with different average rainfall on the wood basic density, Fernandes et al. (2011) verified that a higher wood yield was obtained in the region with higher average precipitation, and that yield negatively influenced the wood density.

The results reported in the literature for correlation between productivity and wood density are still contradictory and may be negative, positive or null; therefore, it was verified that this negative correlation between basic density and productivity found by Fernandes et al. (2011) did not apply to most of the clones in the present study, since the basic density for six of the seven clones studied was higher in Nova Almeida, where the highest average values of the dendrometric characteristics were also obtained, and this is a desirable behavior as it indicates the possibility of selecting high productivity and high basic density clones, which are two essential parameters in genetic breeding programs.

Similar behavior to that observed in this study was found by Castelo (2008), when analyzing the quality of Pinus taeda wood at different growth sites, concluding that wood from a site with a higher growth rate and a site with a more clayey texture presents higher specific mass values when compared to wood from lower productivity sites.

Evaluating the genotype $x$ environment interaction becomes of great importance for improvement, since in the case of its existence, there are possibilities of the best genotype being in one environment and not in another. In this context, priority is given to developing genetic materials that are less influenced by the environment and which may be indicated for a larger geographic area.

In this study, clone 4 was the most influenced by the environment, showing no statistical difference between the sites for any of the evaluated characteristics; in contrast, clone 1 had the biggest influence from the site, presenting statistical difference for all the characteristics. Clone 3 was characterized by the highest weighted average basic density values and basic density in the DBH for both growth sites, as well as being slightly influenced by the environment (base density DBH only).

Clones 1 and 7 were the only ones that presented significant statistical difference between the sites for the tree bark volume, with average values of $0.10 \mathrm{~m}^{3}$ and $0.09 \mathrm{~m}^{3}$, respectively, in Nova Almeida and $0.06 \mathrm{~m}^{3}$ for both clones in Posto da Mata. Thus, the bark volume was not influenced by the environment in most of the studied clones.

Regarding the heartwood and sapwood content, only the clone effect was significant, meaning that this characteristic was not influenced by the environment (Table 5). Heartwood content ranged from $60.9 \%$ to $51.9 \%$, and sapwood content from $48.1 \%$ to $39.1 \%$. Boschetti, Paes, Vidaurre et al. (2015) found lower heartwood and larger sapwood percentages for a 6-year-old Eucalyptus grandis $\times$ Eucalyptus urophylla clone, with mean percentage values equal to $41.6 \%$ and $58.4 \%$, respectively.

According to Sacco et al. (2002), the higher the heartwood content in the wood, the higher the alkali consumption in the pulping process, and there will consequently be yield losses. This is due to the high extractive and lignin content present in the heartwood region. 
Table 5. Mean values per site and clone for the heartwood and sapwood content in the 6.5-year-old E. grandis $\times$ E. urophylla hybrid wood.

\begin{tabular}{|c|c|c|c|c|c|c|c|c|c|}
\hline \multirow{2}{*}{ Variables } & \multicolumn{2}{|c|}{ Location } & \multicolumn{7}{|c|}{ Clones } \\
\hline & NA & PM & 1 & 2 & 3 & 4 & 5 & 6 & 7 \\
\hline Heartwood\% & $56.1 \mathrm{a}$ & $43.8 \mathrm{a}$ & $60.9 \mathrm{a}$ & $54.7 \mathrm{~b}$ & $59.3 \mathrm{a}$ & $51.9 \mathrm{~b}$ & $55.5 \mathrm{~b}$ & $58.0 \mathrm{a}$ & $52.8 \mathrm{~b}$ \\
\hline Sapwood\% & $56.2 \mathrm{a}$ & $43.9 \mathrm{a}$ & $39.1 \mathrm{~b}$ & $45.3 \mathrm{a}$ & $40.7 \mathrm{~b}$ & $48.1 \mathrm{a}$ & $44.5 \mathrm{a}$ & $42.0 \mathrm{~b}$ & $47.2 \mathrm{a}$ \\
\hline
\end{tabular}

NA: Nova Almeida (ES); PM: Posto da Mata (BA). Means followed by the same letter do not differ from each other by the Scott-Knott test $(\mathrm{p}>0.05)$

\subsection{Anatomical analysis of wood}

The clone $\times$ location interaction was significant $(\mathrm{p} \leq 0.05)$ for vessel diameter, fiber length and width, lumen diameter and wall thickness (Table 6). Thus, we performed an analysis of the interaction and comparison of means (Table 7).

In general, vessel characteristics were poorly influenced by the environment, since only two of the seven studied clones presented a statistical difference between sites for vessel diameter, and vessel frequency was not influenced by the site for any of the clones.

Only the effect of the clone was significant for the vessel frequency, and maximum values of $10.16 \mathrm{~mm}^{-2}$, minimum of $6.68 \mathrm{~mm}^{-2}$ and $8.10 \mathrm{~mm}^{-2}$ pores were obtained (Table 8). According to Evangelista (2010) and Lima et al. (2011), larger tangential vessel diameters are usually associated with lower frequencies; a tendency also observed in this work.

The mean values obtained for vessels are in accordance with the studies performed for the 6-yearold $E$. grandis $\times$ E. urophylla (Boschetti, Paes, Oliveira et al., 2015) and for the also 6-year-old E. urophylla (Evangelista, 2010), which found vessel diameters of
$125.0 \mu \mathrm{m}$ to $118.3 \mu \mathrm{m}$, respectively, and mean frequency of $10.0 \mathrm{~mm}^{-2}$ to $9.9 \mathrm{~mm}^{-2}$ pores, respectively.

For the fiber size, it was generally found that the fiber length, width and lumen diameter were similarly influenced by the environment, since only three of the seven studied clones were not influenced by the environment for these characteristics, while the wall thickness showed the lowest effect of the site on its values.

The average values of fiber length presented a maximum of $1127.9 \mu \mathrm{m}$ (clone 6, Posto da Mata) and minimum of $966.8 \mu \mathrm{m}$ (clone 5, Nova Almeida). Close values were found by Evangelista (2010) with a fiber length of $950 \mu \mathrm{m}$ for the 6-year-old E. urophylla wood, while Gomide et al. (2005) found a mean value of $990 \mu \mathrm{m}$ length for eucalyptus, and Trugilho et al. (2007) obtained a mean of $930 \mu \mathrm{m}$ for wood fiber length of 6-year-old eucalyptus clones.

According to Gomide et al. (2005), the shorter fibers contribute to good sheet formation, while the longer fibers favor tear strength. This variability among the clones indicates that the materials may present pulps with different behaviors in both the sheet forming process and in the paper properties.

Table 6. Summary of variance analysis for vessel diameter and frequency and wood fiber dimensions.

\begin{tabular}{lccccccc} 
& & \multicolumn{5}{c}{ Means squared } \\
\cline { 3 - 7 } VF & DF & $\begin{array}{c}\text { Vessel } \\
\text { diameter } \\
(\mu \mathrm{m})\end{array}$ & $\begin{array}{c}\text { Vessel } \\
\text { frequency } \\
\left(\text { pores } \mathbf{~ m m}^{-2}\right)\end{array}$ & $\begin{array}{c}\text { Fiber length } \\
(\mu \mathrm{m})\end{array}$ & $\begin{array}{c}\text { Fiber } \\
\text { thickness } \\
(\mu \mathrm{m})\end{array}$ & $\begin{array}{c}\text { Lumen } \\
\text { diameter } \\
(\mu \mathrm{m})\end{array}$ & $\begin{array}{c}\text { Wall } \\
\text { thickness } \\
(\mu \mathrm{m})\end{array}$ \\
$\mathrm{CL}$ & 6 & $960.940^{* *}$ & $10.838^{* *}$ & $34074.21^{* *}$ & $5.548^{* *}$ & $6.459^{* *}$ & $3.425^{* *}$ \\
$\mathrm{~L}$ & 1 & $549.975^{* *}$ & $0.716^{\text {ns }}$ & $15144.68^{* *}$ & $88.909^{* *}$ & $62.040^{* *}$ & $0.605^{*}$ \\
$\mathrm{CL} \times \mathrm{L}$ & 6 & $223.688^{* *}$ & $1.126^{\text {ns }}$ & $9321.14^{* *}$ & $8.804^{* *}$ & $8.573^{* *}$ & $0.438^{* *}$ \\
Error & 56 & 98.195 & 0.668 & 2023.27 & 1.199 & 1.415 & 0.125 \\
\hline $\mathrm{CVe}$ & & 8.837 & 10.094 & 4.253 & 5.441 & 11.974 & 6.942 \\
\hline $\mathrm{VF}$ & & &
\end{tabular}

VF: variation factor; DF: degrees of freedom; CL: clone; L: location; CL $\times$ L: clone $\times$ location interaction; CVe: experimental coefficient of variation (\%). 
Table 7. Multiple comparison among means for the characteristics of the vessels and fibers for the 6.5-year-old E. grandis $\times$ E. urophylla clones in different locations.

\begin{tabular}{ccccccccc} 
Var. & Loc. & Clone 1 & Clone 2 & Clone 3 & Clone 4 & Clone 5 & Clone 6 & Clone 7 \\
\multirow{2}{*}{ VD } & NA & $111.34 \mathrm{bA}$ & $123.83 \mathrm{aA}$ & $107.76 \mathrm{bB}$ & $112.31 \mathrm{bA}$ & $104.38 \mathrm{bA}$ & $109.25 \mathrm{bB}$ & $96.45 \mathrm{bA}$ \\
& PM & $102.09 \mathrm{cA}$ & $126.85 \mathrm{aA}$ & $125.08 \mathrm{aA}$ & $121.57 \mathrm{aA}$ & $110.75 \mathrm{bA}$ & $124.38 \mathrm{aA}$ & $93.84 \mathrm{cA}$ \\
\hline \multirow{2}{*}{ FL } & NA & $1080.4 \mathrm{aA}$ & $1037.3 \mathrm{bB}$ & $1119.1 \mathrm{aB}$ & $1016.7 \mathrm{bB}$ & $966.8 \mathrm{bA}$ & $1077.9 \mathrm{aA}$ & $1002.1 \mathrm{bA}$ \\
& PM & $984.0 \mathrm{cB}$ & $1114.3 \mathrm{bA}$ & $1179.2 \mathrm{aA}$ & $1097.1 \mathrm{bA}$ & $981.5 \mathrm{cA}$ & $1127.9 \mathrm{bA}$ & $1022.1 \mathrm{cA}$ \\
\multirow{2}{*}{ FW } & NA & $20.6 \mathrm{aA}$ & $19.4 \mathrm{aB}$ & $20.9 \mathrm{aA}$ & $18.0 \mathrm{bB}$ & $17.6 \mathrm{bB}$ & $17.6 \mathrm{bB}$ & $19.0 \mathrm{bA}$ \\
& PM & $20.6 \mathrm{bA}$ & $22.1 \mathrm{aA}$ & $21.3 \mathrm{aA}$ & $22.8 \mathrm{aA}$ & $21.2 \mathrm{aA}$ & $21.2 \mathrm{aA}$ & $19.6 \mathrm{bA}$ \\
& ND & $9.8 \mathrm{aA}$ & $9.6 \mathrm{aA}$ & $8.2 \mathrm{bB}$ & $9.1 \mathrm{aB}$ & $7.3 \mathrm{bB}$ & $8.8 \mathrm{aB}$ & $10.2 \mathrm{aA}$ \\
& PM & $9.2 \mathrm{bA}$ & $10.8 \mathrm{bA}$ & $9.9 \mathrm{bA}$ & $13.3 \mathrm{aA}$ & $10.8 \mathrm{bA}$ & $12.1 \mathrm{aA}$ & $10.1 \mathrm{bA}$ \\
\hline \multirow{2}{*}{ WT } & NA & $5.4 \mathrm{bA}$ & $4.9 \mathrm{bB}$ & $6.4 \mathrm{aA}$ & $4.5 \mathrm{cA}$ & $5.2 \mathrm{bA}$ & $4.4 \mathrm{cA}$ & $4.4 \mathrm{cA}$ \\
& PM & $5.7 \mathrm{aA}$ & $5.6 \mathrm{aA}$ & $5.7 \mathrm{aB}$ & $4.7 \mathrm{bA}$ & $5.2 \mathrm{aA}$ & $4.5 \mathrm{bA}$ & $4.8 \mathrm{bA}$ \\
\hline
\end{tabular}

Var.: variables; Loc.: location; NA: Nova Almeida (ES); PM: Posto da Mata (BA); VD: Vessel Diameter ( $\mu$ m); FL: Fiber length ( $\mu$ m); FW: Fiber width $(\mu \mathrm{m})$; LD: Lumen diameter $(\mu \mathrm{m})$; WT: Wall thickness $(\mu \mathrm{m})$. Means followed by the same lowercase letter in the row and uppercase in the column do not differ from each other by the Scott-Knott test $(p>0.05)$.

Table 8. Mean values per site and clone for the vessel frequency of the 6.5-year-old E. grandis $\times$ E. urophylla hybrid wood.

\begin{tabular}{|c|c|c|c|c|c|c|c|c|c|}
\hline \multirow{2}{*}{ Variable } & \multicolumn{2}{|c|}{ Location } & \multicolumn{7}{|c|}{ Clones } \\
\hline & NA & PM & 1 & 2 & 3 & 4 & 5 & 6 & 7 \\
\hline VF & $8.0 \mathrm{a}$ & $8.2 \mathrm{a}$ & $7.82 \mathrm{~b}$ & $7.77 \mathrm{~b}$ & $8.15 \mathrm{~b}$ & $8.18 \mathrm{~b}$ & $7.94 \mathrm{~b}$ & $6.68 c$ & $10.16 \mathrm{a}$ \\
\hline
\end{tabular}

NA: Nova Almeida (ES); PM: Posto da Mata (BA); VF: vessel frequency (pores. $\mathrm{mm}^{-2}$ ). Means followed by the same letter do not differ from each other by the Scott-Knott Test $(p>0.05)$.

When evaluating the wood quality of eucalyptus clones, Trugilho et al. (2007) found lower values than those obtained in this study for fiber width and wall thickness, with mean values of $16.31 \mu \mathrm{m}$ and $2.35 \mu \mathrm{m}$, respectively, as well as close values for the lumen diameter with a mean of $11.61 \mu \mathrm{m}$ for a 5.9-year-old $E$. grandis $\times$ E.urophylla with a basic density of $0.50{\mathrm{~g} . \mathrm{cm}^{-3}}^{-3}$.

The wall thickness presented minimum values of $4.4 \mu \mathrm{m}$ (clones 6 and 7, Nova Almeida) and maximum of $6.4 \mu \mathrm{m}$ (clone 3, Nova Almeida), and this characteristic of the fibers is important for manufacturing papers as it can be correlated with the coarseness of the pulp. In general, high coarseness values in eucalyptus pulps are associated with thick-walled fibers, which are rigid and more difficult to collapse, produce a looser, more porous, bulky, absorbent and without much fiber bonding mesh paper (Gomide et al., 2005; Foelkel, 2009).

It is also known that the cell wall thickness is associated with wood basic density, as can be observed for clone 3 in Nova Almeida, which presented the highest basic density $\left(0.59 \mathrm{~g} . \mathrm{cm}^{-3}\right)$ and also greater wall thickness $(6.4 \mu \mathrm{m})$. According to Mokfienski et al. (2008), eucalyptus wood with lower density, which usually has thinner walls, can be directed to producing writing and printing papers due to their anatomical characteristics, while the woods are denser for the absorbent paper segment.

\section{CONCLUSIONS}

Among all the evaluated characteristics, the heartwood and sapwood percentage and vessel frequency were the only characteristics not influenced by the environment, presenting no significant statistical difference for either the clone $\times$ location interaction or the site alone. Furthermore, the characteristics of bark volume, weighted mean basic density, vessel diameter and wall thickness may be considered as being little influenced by the environment. On the other hand, tree height (total and commercial) was considered the most influenced by the environment.

The highest mean values of the evaluated dendrometric characteristics, and therefore the highest growth, were always obtained in the site with medium/clay texture soil and the highest amount of organic matter in the primary and secondary soil layers, thus indicating that 
even though precipitation did not vary much between the two sites, these other combined soil and climatic characteristics resulted in better tree development.

For most of the studied clones, the wood basic density was higher at the site where the highest dendrometric values were also obtained, thus confirming the possibility of selecting clones which present high productivity without losses in the wood basic density values.

\section{SUBMISSION STATUS}

Received: 1 June, 2016

Accepted: 30 June, 2018

\section{CORRESPONDENCE TO}

\section{Thaís Pereira Freitas}

Universidade Federal de Viçosa (UFV), Engenharia Florestal, Av. Purdue, s/n, Campus Universitário, CEP 36570-900, Viçosa, MG, Brasil e-mail: thais_pfreitas@yahoo.com.br

\section{FINANCIAL SUPPORT}

The authors thank Fundação de Amparo à Pesquisa e Inovação do Espírito Santo (Fapes), Coordenacão de Aperfeiçoamento de Pessoal de Nível Superior (Capes) and Fíbria Celulose S.A. for the financial support.

\section{REFERENCES}

Associação Brasileira de Normas Técnicas - ABNT. NBR6230: métodos de ensaio para madeiras. Rio de Janeiro; 1985.

Associação Brasileira de Normas Técnicas - ABNT. NBR11941: madeira - determinação da densidade básica. Rio de Janeiro; 2003.

Boschetti WTN, Paes JB, Oliveira JTS, Dudecki L. Características anatômicas para produção de celulose do lenho de reação de árvores inclinadas de eucalipto. Pesquisa Agropecuária Brasileira 2015; 50(6): 459-467. 10.1590/S0100-204X2015000600004

Boschetti WTN, Paes JB, Vidaurre GB, Arantes MDC, Leite FP. Parâmetros dendrométricos e excentricidade da medula em árvores inclinadas de eucalipto. Scientia Forestalis 2015; 43(108): 781-789. 10.18671/scifor. $\mathrm{v} 43 \mathrm{n} 108.4$

Carvalho AM, Nahuz MAR. Valorização da madeira do híbrido Eucalyptus grandis $\times$ urophylla através da produção conjunta de madeira serrada em pequenas dimensões, celulose e lenha. Scientia Forestalis 2001 [cited 2019 May 24]; (59): 61-76. Available from: http://bit. ly/30ljMdz

Castelo PAR, Matos JLM, Dedecek RA, Lavoranti, OJ. Influência de diferentes sítios de crescimento sobre a qualidade da madeira de Pinus taeda. Floresta 2008; 38(3): 495-506. 10.5380/rf.v38i3.12416

Comisión Panamericana de Normas Técnicas - Copant. Descripción de características generales, macroscópicas de las maderas angiospermas dicotiledóneas. Buenos Aires; 1974.

Dadswell HE. The anatomy of eucalypt wood. Forest Products Laboratory 1972; (66): 1-28.

Evangelista WV, Silva JC, Valle, MLA, Xavier BA. Caracterização anatômica quantitativa da madeira de clones de Eucalyptus camaldulensis Dehnh.e Eucalyptus urophylla S.T. Blake. Scientia Forestalis 2010 [cited 2019 May 24]; 38(86): 273-284. Available from: http://bit. ly/30hAVoJ

Fernandes DE, Gomide JL, Colodette JL, Ferreira MZ. Influência da produtividade de clones híbridos de eucalipto na densidade da madeira e na polpação Kraft. Scientia Forestalis 2011 [cited 2019 May 24]; 39(90): 143150. Available from: http://bit.ly/2LMjlWw

Ferreira M. Características da madeira de espécies/ procedências/árvores superiores e clones de Eucalyptus: revisão aplicada ao melhoramento para produção de pasta celulósica. In: Anais da $1^{\text {a }}$ Reunião Regional sobre Clonagem Intensiva em Eucalyptus; 1994 Jun; Aracruz, Espírito Santo. Piracicaba: Instituto de Pesquisas e Estudos Florestais; 1994.

Foelkel C. Propriedades papeleiras das árvores, madeiras e fibras celulósicas dos eucaliptos. In: Associação Brasileira Técnica de Celulose e Papel, editora. Eucalyptus online book. São Paulo; 2009 [cited 2019 May 24]. Available from: http://bit.ly/2HpHmgT

Gomide JL, Colodette JL, Oliveira RC, Silva CM. Caracterização tecnológica, para produção de celulose, da nova geração de clones de Eucalyptus do Brasil. Revista Árvore 2005; 29(1): 129-137. 10.1590/S010067622005000100014

Gomide JL, Fantuzzi Neto H, Regazzi A.J. Análise de critérios de qualidade da madeira de eucalipto para produção de celulose kraft. Revista Árvore 2010; 34(2): 339-344. 10.1590/S0100-67622010000200017

Gouvea AFG, Gomes CM, Matos LM, Souza TA, Kumabe FJB, Benites PKRM. Efeito do sítio nas características tecnológicas da madeira de Eucalyptus para produção de celulose kraft. Ciência da Madeira 2012; 3(2): 102-115. 10.15210/cmad.v3i2.4041

Indústria Brasileira de Árvores - Idá. Anuário estatístico 2015. Brasília, DF; 2015. 
Lima IL, Garcia R, Longui EL, Florsheim SMB. Dimensões anatômicas da madeira de Tectona grandis Linn. em função do espaçamento e da posição radial do tronco. Scientia Forestalis 2011 [cited 2019 May 24]; 39(89): 6168. Available from: http://bit.ly/2Q642GA

Mokfienski A, Colodette JL, Gomide JL, Carvalho AMMC. A importância relativa da densidade da madeira e do teor de carboidratos no rendimento de polpa e na qualidade do produto. Ciência Florestal 2008; 18(3): 401-413. 10.5902/19805098451

Sacco MPR, Ferreira CSR, Sansígolo CA. Efeito do cerne e alburno na produção de celulose kraft em cavacos de Eucalyptus grandis. In: Anais da 9a Reunião Científica em Ciências Agrárias do Lageado; 2002 Oct 7-11; Botucatu,
São Paulo. Botucatu: Faculdade de Ciências Agronômicas; 2003. CD-ROM

Sturion JA. Controle genético da densidade básica da madeira de Eucalyptus viminalis Labill. Colombo: Embrapa Florestas; 2008.

Trugilho PF. Densidade básica e estimativa de massa seca e de lignina na madeira em espécies de Eucalyptus. Ciência e Agrotecnologia 2009; 33(5): 1228-1239. 10.1590/ S1413-70542009000500005

Trugilho PF, Bianchi ML, Rosado SCS, Lima JT. Qualidade da madeira de clones de espécies e híbridos naturais de Eucalyptus. Scientia Forestalis 2007 [cited 2019 May 24]; (73): 55-62. Available from: http://bit.ly/2HjrUEa 